\title{
Analysis of the Corrosion Products of the Ancient Bronzes Excavated from Qiaojiayuan Tombs
}

\author{
Wugan Luo \& Rui Jin \\ Department of Scientific History and Archaeometry \\ Graduate University of Chinese Academy of Sciences, Beijing 100049, China \\ $\&$ \\ The Joint Laboratory of China and Germany \\ Human Evolution and Archaeometry, Beijing 100044, China \\ Tel: 86-10-8852-6452_E-mail: xiahua@gucas.ac.cn \\ Ying Qin \\ The Laboratory of Archaeometry \\ University of Science and Technology of China, Hefei 230026, China \\ Tel: 86-551-360-3576_E-mail: yingqin@ustc.edu.cn \\ Fengchun Huang \\ Institution of Cultural Relics and Archaeology of Hubei Province \\ Wuhan 430077, China \\ E-mail: homehfc@sina.com \\ Changsui Wang \\ Department of Scientific History and Archaeometry \\ Graduate University of Chinese Academy of Sciences, Beijing 100049, China \\ $\&$ \\ The Joint Laboratory of China and Germany \\ Human Evolution and Archaeometry, Beijing 100044, China \\ Tel: 86-10-8825-6180Ｅ-mail: cswang@gucas.ac.cn
}

The research is supported by the Knowledge Innovation Engineering Project of Chinese Academy of Sciences (No. KJCX3, SYW, N12) and the Post-doctoral Fund (No. 20090460567). (Sponsoring information)

\begin{abstract}
XRD, Raman analysis, and metallographic analysis are used to identify corrosion products of ancient bronzes excavated from Qiaojiayuan tombs, and the result indicates that the corrosion products mainly includes $\mathrm{Cu}_{2} \mathrm{CO}_{3}(\mathrm{OH})_{2}, \mathrm{Cu}_{3}(\mathrm{OH})_{2}\left(\mathrm{CO}_{3}\right)_{2}, \mathrm{Cu}_{2} \mathrm{O}, \mathrm{Cu}_{2} \mathrm{Cl}(\mathrm{OH})_{3}, \mathrm{CuCl}_{2} \cdot 2 \mathrm{H}_{2} \mathrm{O}, \mathrm{PbCO}_{3}$ and $\mathrm{SiO}_{2}$. It was found that these ancient bronzes were preserved in a chloric, acidity, and seasonal changed environment. In addition, the $\delta$ phase of the eutectoid was corroded preferentially in this environment. There are lots of corrosion types in these bronzes, such as electrochemistry corrosion, hole-corrosion, and dot-corrosion. The corrosion products generally have copper oxychloride, moisture copper chloride and other copper chlorination corrosions, and the position of the powdery corrosion presents the rust layer structure of "copper- cuprite- paratacamite- malachite- azurite". At the same time, the corrosion principles of the bronzes are discussed, and the simple methods scientifically protecting these bronzes are suggested in the final part of the article.
\end{abstract}

Keywords: Qiaojiayuan ancient tombs, Corrosion products, XRD and Raman spectral analysis, Metallographic analysis 
From March to December of 2006, the Institution of Cultural Relics and Archaeology of Hubei Province had explored and disentombed the Qiaojiayuan tombs in Wufeng Town of Yun City with other units in the South-North Water Transfer Project. When the site begun to discover, it was extensively concerned by the archaeology circle, the historical circle, and the social public because its geographical location was same with the "Yang XUE" of the ancient capital of the Jun Country recorded in the historical literatures. In the December of that year, the Qiaojiayuan Chun Qiu tombs had been evaluated as the "major archeological discovery" by the State Cultural Relic Bureau of China. The scientific disentombment of Qiaojiayuan Tombs could not only open out the prelude of the archeology cultural research of ancient Jun Country, but provide sufficient materials for the comprehensive research of the bronzes in the ancient Jun Country because of the discover of numerous fine bronzes. However, the preservation situation of these bronzes are bad, and the corrosion types are numerous, including hard and compact cyan corrosion, loosen and powdery wax-white corrosion. To deeply know the preservation actuality of these bronzes, discuss the corrosion behaviors of the bronzes relic in the local embedding environment, and provide scientific and exact reference information for the subsequent historic preservation, it is necessary to analyze the corrosion products of these bronzes. In this article, many analysis methods such as XRD, Raman spectral analysis, and metalloscope are used to analyze the corrosion products of these bronzes, and the corrosion mechanism was primarily discussed. Based on that, the simple preservation project is suggested.

\section{Experiment analysis}

\subsection{XRD analysis}

By scratching the corrosion products from the bronzes by the scalpel, twelve corrosion samples were obtained. These samples come from different tombs, including different types of wares with different colors, and they could completely reflect the corrosion situation of all bronzes.

After being grinded to tiny powders in the agate mortars, the corrosion samples are sent to the Physical and Chemical Scientific Experiment Center of the University of Science and Technology of China for XRD analysis. The instrument used in the experiment is the D/max-rA target-turning X-Ray DiffractomerX made by the Japan Rigaku Company, and the $\mathrm{X}$ light-source is the $\mathrm{K} \alpha$ radiation of $\mathrm{Cu}$ target, and the work pipe pressure and the pipe flow respectively are $40 \mathrm{KV}$ and $100 \mathrm{~mA}$, and the scanning angle range $(2 \theta)$ is $10 \sim 70^{\circ}$, and the scale is 2000 counts $/ \mathrm{min}$. The introduction and analysis result of samples are seen in Table 1, and the spectrogram of XRD is seen in Figure 1 Figure 12.

The XRD analysis result shows that the type of the bronzes corrosion product disentombed in Qiaojiayuan are numerous, and the compounds containing copper include green malachite $\left(\mathrm{Cu}_{2} \mathrm{CO}_{3}(\mathrm{OH})_{2}\right)$, blue aeurite $\left(\mathrm{Cu}_{3}(\mathrm{OH})_{2}\left(\mathrm{CO}_{3}\right)_{2}\right)$, red cuprite $\left(\mathrm{Cu}_{2} \mathrm{O}\right)$, jade-green paratacamite $\left(\mathrm{Cu}_{2} \mathrm{Cl}(\mathrm{OH})_{3}\right)$, Cambridge blue green hydrous copper chloride $\left(\mathrm{CuCl}_{2} \cdot 2 \mathrm{H}_{2} \mathrm{O}\right)$, and the compound containing lead mainly includes white cerusite $\left(\mathrm{PbCO}_{3}\right)$, and part samples still contain some white or flint quartz $\left(\mathrm{SiO}_{2}\right)$ brought from soils.

\subsection{Raman spectral analysis}

Raman spectrum is the molecule spectrum, and different substances have different Raman spectrums, like human finger marks. Therefore, according to the Raman spectrum of the substance, its molecule composition could be confirmed theoretically. The laser micro Raman spectrum has many advantages such as lossless and high space resolving capability, strong anti-jamming, convenient use, and small facular, and it has been extensively applied in the research domains such as archaeology and artwork (Gregory D Smith, 2004, P.1137-1160).

According to the observation, the samples Q63 and Q64 have some point-wax-white corrosion products, and to confirm its phase, the Raman spectral analysis is adopted to analyze this white substance.

The Raman spectral analysis experiment of the sample is implemented in the Physical and Chemical Scientific Experiment Center of the University of Science and Technology of China, the used instrument is the LABRAM-HR Confocal Laser Micro-Raman Spectroscopy made by the French JY Company. The argon ion laser is adopted, and the laser wave length is $514.5 \mathrm{~nm}$. The wave amount is in $100-1800 \mathrm{~cm}^{-1}$, and the precision of wave amount is $\pm 1 \mathrm{~cm}^{-1}$, and the object lens is $50 \times$, and the facular size is 1 micron. The Raman spectral analysis result of the sample is seen in Figure 2.

The Raman spectral analysis result indicates that the Raman spectrum of Q63 is similar with the Raman spectrum of Q64, and their positions of characteristic peak are same, so the corrosion products of these two bronzes are consistent, i.e. the atacamite $\left(\mathrm{Cu}_{2} \mathrm{Cl}(\mathrm{OH})_{3}\right)$. 


\section{Research results}

The research shows that the corrosions of bronzes include two types (Lowell I McCann, 1999, P.121-132), and the first corrosion type can be described by that in the eutectoid mixture of $(\alpha+\delta)$, the phase of $\delta$ with $32.6 \%$ tin would be corroded firstly, which is generally induced by the transfer of anions such as $\mathrm{Cl}$ in the alloy. And the second corrosion type can be described by that the phase of $\alpha$ would be corroded first, which is generally induced by the transfer of $\mathrm{Cu}^{+}\left(\mathrm{Cu}^{2+}\right)$ from the interior to the surface in the alloy. Obviously, different corrosion types indicate different bronze preservation environments.

The metallographic analysis of Q57, Q63, and Q64 indicates that the arborization segregation $\alpha$ solid solution $(\alpha+\delta)$ eutectoid mixture is distributed along intercrystalline porosity. The common characteristic of these three samples is that the $(\alpha+\delta)$ eutectoid mixture would be corroded first, but the solid solution was preserved well. In addition, the pure copper grains could be found, which was more representative in Q57 (seen in Figure 15 17).

Figure 15 17 indicates that these three samples belong to the first type of corrosion, and these bronzes were in the preservation environment full of chlorine. The component analysis of tomb soils also shows that these soils contain certain chlorine (seen in Table 3), which is consistent with the above analysis result. The soil type of the Wufeng Town of Yun County where the tombs are belongs to the pelyte yellow brown soil, and its $\mathrm{pH}$ value is in 5.4 7.2. It is obvious that these bronzes had been in the chloric acid environment for a long time.

Chinese and foreign scholars have studied the corrosion mechanism of bronzes in the chloric bronzes (Fan, 1992, P.685-689 \& I. Constantinides, 2002, P.90-101 \& Fan, 1997, P.20-24 \& Fan, 1991, P.239 \& Cheng, 1989, P.30), and they generally thought that one of the corrosion approaches of the chlorine ion to the copper in the acid environment is

$$
\mathrm{Cu} \rightarrow \mathrm{Cu}^{+} \rightarrow \mathrm{Cu}^{2+}
$$

In the condition full of oxygen, when the bronzes contact with chlorine ions, following reaction will occur easily.

$$
4 \mathrm{Cu}+4 \mathrm{HCl}+\mathrm{O}_{2}=4 \mathrm{CuCl}+2 \mathrm{H}_{2} \mathrm{O}
$$

The generated $\mathrm{CuCl}$ is a kind of photosensitive substance, and it will change to $\mathrm{CuCl}_{2}, \mathrm{CuCl}_{2} \cdot 2 \mathrm{H}_{2} \mathrm{O}, \mathrm{Cu} 2 \mathrm{Cl}(\mathrm{OH})_{3}$ and some cupric chlorides. And the reactions are in turn

$$
\begin{gathered}
4 \mathrm{CuCl}+1 / 2 \mathrm{O}_{2}=2 \mathrm{CuCl}_{2}+\mathrm{Cu}_{2} \mathrm{O} \\
4 \mathrm{CuCl}+4 \mathrm{H}_{2} \mathrm{O}+1 / 2 \mathrm{O}_{2}=2\left[\mathrm{CuCl}_{2} \cdot 2 \mathrm{H}_{2} \mathrm{O}\right]+\mathrm{Cu}_{2} \mathrm{O} \\
4 \mathrm{CuCl}+4 \mathrm{H}_{2} \mathrm{O}+\mathrm{O}_{2}=2\left[\mathrm{Cu}_{2} \mathrm{Cl}(\mathrm{OH})_{3}\right]+2 \mathrm{HCl} .
\end{gathered}
$$

The $\mathrm{HCl}$ generated in the reaction will from the cycled reaction, which will further quicken the corrosion of copper until the bronzes are corroded to the core, and finally become a pile of powders.

Because the groundwater level of the Qiaojiayuan tombs is lower, and the cultural relics preserved under the ground was largely influenced by the surface water. With the seasonal dry-wet change, the surface water filtered into the tombs with oxygen, $\mathrm{CO}_{2}$, and some acid substances in the air, which would quicken the transfer of positive and negative ions in the soils, and make the bronzes in the "bad" preservation environment with seasonal change. In this preservation process, the bronzes would generate various corrosions, which is the main cause that the bronzes in the ancient Jun Country were corroded so seriously.

In the research, for different parts of same one bronze, the corrosion types and degrees are always different, but if the crevice exists, the corrosion at this crevice would be more serious. The metal corrosion theory indicates that when the crevice exits between two metals, the solution with the chlorine ions would easily induce the crevice corrosion (Yang, 1999, P.132). As seen in Figure 18, at the crevice between the copper scoop handle with the scoop body, the corrosion is quite serious, and the wax-white corrosion product is the hydrous copper chloride through XRD analysis. And in another copper scoop sample, the handle and the body have completely separated (seen in Figure 19). So it can be adjudged that above two samples had the crevice corrosion.

The interior bottom of the M5:1 copper scoop has four powdery corrosion points, and the XRD analysis indicates that these white powdery corrosion points mainly are the paratacamite with malachite and cuprite. Figure 20 is the picture that the bottom of the copper scoop is magnified, and when the powdery corrosion is eliminated, the wine substances occur, and by the XRD analysis (Figure 9), these wine substances are cuprite. And the green and aqua corrosions covered around the powdery corrosion mainly are the corrosion of malachite. According to the unaided eye observation and XRD analysis result, this copper scoop sample presents the rust layer structure of "copper- cuprite- paratacamite- malachite- azurite". Its forming mechanism generally follows following rules. In the using process before the bronze is preserved, because of heat, it will react with the oxygen 
in the air, and the layer of cuprite forms. This corrosion layer generally is compact, which could prevent the development of corrosion and protect the bronzes. However, after the bronzes are preserved under the ground, because of the influences of many factors such as chlorine ions, acid condition, and seasonal dry-wet change, the layer of cuprous oxide will change to copper chloride hydroxide, and the expansion function of the copper chloride hydroxide will provide the channel for chlorine ions, oxygen, and waters in the preservation environment to enter into the interior of the bronzes, so the corrosion reaction will continually happen, and the point-hole corrosion will form. The total reaction process could be described as follows.

$$
\begin{gathered}
\mathrm{Cu}+1 / 2 \mathrm{O}_{2}=\mathrm{Cu}_{2} \mathrm{O} ; \\
2 \mathrm{Cu}_{2} \mathrm{O}+2 \mathrm{HCl}+2 \mathrm{H}_{2} \mathrm{O}+\mathrm{O}_{2}=2\left[\mathrm{Cu}_{2} \mathrm{Cl}(\mathrm{OH})_{3}\right] .
\end{gathered}
$$

Figure 21 is the appearance picture of the interior bottom corrosion of $\mathrm{M} 6: 11$ copper $\mathrm{Yi}$, and it is obvious that the corrosion could be divided into three layers at least, and the bottom layer is the shadow white corrosion, and it is very thin, so the sampling analysis is omitted. Above the shadow white corrosion, the bright green corrosion is covered, and according to the analysis of the bottom corrosion products, this layer should be the malachite. The blue corrosion on the bright green corrosion (Q50) is the azurite with some malachite, paratacamite, and cuprite. Where, green and shadow white corrosion products are brought with the sampling process and the corrosion products clinging to the bronze should be the cuprite. Obviously, this bronze has the same rust layer structure of "copper- cuprite- paratacamite- malachite- azurite", and its corrosion mechanism should be similar with the M5:1 copper scoop.

$\mathrm{XRD}$ analysis shows that except for above chloric copper rusts, in other coppery corrosions, most green corrosions belong to malachite, and most blue corrosions belong to azurite, and cyan corrosions are the admixture of the both. When the preservation environment has water and $\mathrm{CO}_{2}$, the cuprite through oxidation would change to malachite and azurite (Lowell I McCann, 1999, P.121-132). The concrete reaction process can be described as follows.

$$
\begin{gathered}
\mathrm{Cu}_{2} \mathrm{O}+\mathrm{H}_{2} \mathrm{O}+\mathrm{CO}_{2}+1 / 2 \mathrm{O}_{2}=\mathrm{Cu}_{2} \mathrm{CO}_{3}(\mathrm{OH})_{2} ; \\
3 / 2 \mathrm{Cu}_{2} \mathrm{O}+\mathrm{H}_{2} \mathrm{O}+2 \mathrm{CO}_{2}+3 / 4 \mathrm{O}_{2}=\mathrm{Cu}_{3}(\mathrm{OH})_{2}\left(\mathrm{CO}_{3}\right)_{2} .
\end{gathered}
$$

On the bronzes in ancient Jun Country, more green corrosions (malachite) always cover the whole bronze, and the blue corrosion (azurite) is relatively less, and distributes on the green corrosions isolated, which is because that the generation of azurite needs to consume more $\mathrm{CO}_{2}$ and oxygen, so after the malachite generates, it only reacts with surplus $\mathrm{CO}_{2}$ and oxygen, and generates a few azurite.

\section{Conclusions}

(1) The bronzes in the ancient Jun Country were preserved in a chloric, acidity, and seasonal changed environment, and in this environment, the $\delta$ phase of the eutectoid was corroded preferentially, and the electrochemistry corrosion happened mainly, with crevice corrosion and point-hole corrosion. The corrosion types are multiple and the corrosion degree is serious.

(2) These bronzes generally have the copper oxychloride corrosion and hydrous copper chloride corrosion, and at the location of the powdery rust, the rust structure of "copper- cuprite- paratacamite- malachite- azurite" is presented.

(3) Because these bronzes generally have harmful rusts, when protecting these bronzes, the $3 \%$ oxalic acid (acetic acid) should be combined with the mechanical method to eliminate the white cementation corrosions on the surface, and the hard concretion corrosions such as soil rust. Take the processed bronzes into the 3 5\% sodium-carbonate solution, marinate them repeatedly to eliminate the chlorination corrosion to the core. Finally, select proper enveloping materials (such as 2\% PMMA) to envelop these bronzes. When these bronzes are preserved or exhibited, the preservation environment should be controlled well, and the contact with $\mathrm{O}_{2}, \mathrm{CO}_{2}$, and $\mathrm{H}_{2} \mathrm{O}$ should be reduced as far as possible, so are chloride, sulfide, oxynitride, and other corrosive substances.

\section{References}

Cheng, Derun, Zhao, Mingren \& Liu, Cheng et al. (1989). Study on the Powdery Corrosion Mechansim of Ancient Bronzes. Journal of Northwest University, No.1. P.30.

Fan, Chongzheng, Hu, Keliang, Xing, Jinyun et al. (1997). Following Observation of the Bronze Powdery Corrosion Growth Process. Sciences of Conservation and Archaeology, No.5. P.20-24.

Fan, Chongzheng, Wang, Changsui, Wang, Shengjun et al. (1991). Study on the Generation Mechanism of the Bronze Powdery Corrosion. Science in China Series B-Chemistry, No.3. P.239. 
Fan, Chongzheng, Wang, Changsui, Zhao, Huazhang et al. (1992). Study on the Chemical Dynamics of the Cuprous Chloride Oxidation. Acta Physico-chemica Sinica, No.5. P.685-689.

Gregory D Smith, Robin J H Clark. (2004). Raman microscopy in archaeological science. Journal of Archaeological Science, No.31. P.1137-1160.

Ian M Bell, Robin J H Clark, Peter J Gibbs. (1997). Raman spectroscopic library of natural and synthetic pigments (pre-1850AD). Spectrochimica Acta. No.A53. P.2159-2179.

I. Constantinides, A. Adriaens, F. Adams. (2002). Surface characterization of artificial corrosion layers on copper alloy reference materials. Applied Surface Science, No.189. P.90-101.

Lowell I McCann, K Trentelman, T Possley, et al. (1999). Corrosion of Ancient Chinese Bronze Money Trees Studiey by Raman Microscopy. Journal of Raman Spectroscopy, No.30. P.121-132.

Lucia Burigo, Robin J H Clark. (2001). Library of FT-Raman spectra of pigments, minerals, pigment media and varnishes, and supplement to existing library of Raman spectra of pigments with visible excitation. Spectrochimica Acta, No.A57. P.1491-1521.

M Bouchard, D C Smith. (2003). Catalogue of 45 reference Raman spectra of minerals concerning research in art history or archaeology, especially on corroded metals and colored glass. Spectrochimica Acta, No.A 59. P.2247-2266.

Yang, Dejun \& Shen, Zhuoshen. (1999). Mental Corrosion. Beijing: Metallurgical Industry Press. P.132.

Table 1. Results of XRD Analysis

\begin{tabular}{|c|c|c|c|c|}
\hline No. & $\begin{array}{l}\text { Registration } \\
\text { No. }\end{array}$ & Sample description & $\begin{array}{l}\text { XRD } \\
\text { spectra }\end{array}$ & Chemical formula \\
\hline Q6 & M4 & $\begin{array}{l}\text { Corrosion of bronze } \\
\text { sword }\end{array}$ & Fig. 1 & $\mathrm{Cu} 2 \mathrm{O}, \mathrm{Cu} 2 \mathrm{CO} 3(\mathrm{OH}) 2, \mathrm{PbCO} 3, \mathrm{SiO} 2$ \\
\hline Q-38 & M5:5 & $\begin{array}{l}\text { Pea green corrosion of } \\
\text { bronze Ding }\end{array}$ & Fig. 2 & $\mathrm{Cu} 2 \mathrm{CO} 3(\mathrm{OH}) 2, \mathrm{PbCO} 3, \mathrm{SiO} 2, \mathrm{Cu} 2 \mathrm{O}$ \\
\hline Q-41 & M4:5 & $\begin{array}{l}\text { Wax-white corrosion of } \\
\text { bronze scoop }\end{array}$ & Fig. 3 & $\mathrm{PbCO} 3, \mathrm{Cu} 2 \mathrm{CO} 3(\mathrm{OH}) 2, \mathrm{CuCl} 2 \cdot 2 \mathrm{H} 2 \mathrm{O}, \mathrm{Cu} 2 \mathrm{O}$ \\
\hline Q-42 & M6:7 & $\begin{array}{l}\text { Cyan corrosion of } \\
\text { bronze Ding }\end{array}$ & Fig. 4 & $\mathrm{PbCO} 3, \mathrm{Cu} 2 \mathrm{CO} 3(\mathrm{OH}) 2, \mathrm{SiO} 2$ \\
\hline Q-43 & M6:7 & $\begin{array}{l}\text { Cyan corrosion of } \\
\text { bronze Ding }\end{array}$ & Fig. 5 & $\mathrm{PbCO} 3, \mathrm{Cu} 2 \mathrm{CO} 3(\mathrm{OH}) 2$ \\
\hline Q-46 & M6:11 & $\begin{array}{l}\text { Black and green } \\
\text { corrosion bronze Yi }\end{array}$ & Fig. 6 & $\mathrm{Cu} 2 \mathrm{CO} 3(\mathrm{OH}) 2, \mathrm{PbCO} 3, \mathrm{SiO} 2$ \\
\hline Q-48 & M6:11 & $\begin{array}{l}\text { Green corrosion bronze } \\
\mathrm{Yi}\end{array}$ & Fig. 7 & $\mathrm{Cu} 2 \mathrm{CO} 3(\mathrm{OH}) 2, \mathrm{PbCO} 3$ \\
\hline Q-50 & M6:11 & $\begin{array}{l}\text { Blue corrosion bronze } \\
\text { Yi }\end{array}$ & Fig. 8 & $\begin{array}{l}\mathrm{Cu} 3(\mathrm{OH}) 2(\mathrm{CO} 3) 2, \mathrm{Cu} 2 \mathrm{CO} 3(\mathrm{OH}) 2, \\
\mathrm{Cu} 2 \mathrm{Cl}(\mathrm{OH}) 3 \text { (Paratacamite), } \mathrm{Cu} 2 \mathrm{O}\end{array}$ \\
\hline Q-52 & M5:1 & $\begin{array}{l}\text { Wax-white corrosion of } \\
\text { bronze scoop }\end{array}$ & Fig. 9 & $\mathrm{Cu} 2 \mathrm{Cl}(\mathrm{OH}) 3, \mathrm{Cu} 2 \mathrm{O}, \mathrm{Cu} 2 \mathrm{CO} 3(\mathrm{OH}) 2$ \\
\hline Q-54 & M5:14 & $\begin{array}{l}\text { Green corrosion bronze } \\
\text { Pan }\end{array}$ & Fig. 10 & $\mathrm{Cu} 2 \mathrm{CO} 3(\mathrm{OH}) 2, \mathrm{Cu} 2 \mathrm{O}, \mathrm{SiO} 2$ \\
\hline Q-57 & M6:5 & $\begin{array}{l}\text { Aqua corrosion of } \\
\text { bronze } \mathrm{Hu}\end{array}$ & Fig. 11 & $\mathrm{Cu} 2 \mathrm{CO} 3(\mathrm{OH}) 2, \mathrm{Cu} 3(\mathrm{OH}) 2(\mathrm{CO} 3) 2, \mathrm{CuCl} 2 \cdot 2 \mathrm{H} 2 \mathrm{O}$ \\
\hline Q-74 & M6:6 & Corrosion of bronze $\mathrm{Hu}$ & Fig. 12 & $\mathrm{PbCO} 3, \mathrm{Cu} 2 \mathrm{CO} 3(\mathrm{OH}) 2, \mathrm{Cu} 3(\mathrm{OH}) 2(\mathrm{CO} 3) 2, \mathrm{SiO} 2$ \\
\hline
\end{tabular}


Table 2. Results of Raman Spectral Analysis

\begin{tabular}{|c|c|c|c|c|}
\hline Raman spectra & Sample & Raman shift (cm-1) & Chemical formula & Reference \\
\hline Fig. 13 & Q63 & $\begin{array}{l}120,148,214,358,416, \\
450,512,594,818,912,975\end{array}$ & $\begin{array}{l}\mathrm{Cu} 2 \mathrm{Cl}(\mathrm{OH}) 3 \\
\text { Atacamite }\end{array}$ & $\begin{array}{l}\text { (Ian M Bell, } \\
1997, \\
\text { P.2159-2179 \& } \\
\text { M Bouchard, } \\
2003, \\
\text { P.2247-2266 \& } \\
\text { Lucia Burigo, } \\
2001, \\
\text { P.1491-1521) }\end{array}$ \\
\hline Fig. 14 & Q64 & $\begin{array}{l}119,146,267,359, \\
510,821,909,974\end{array}$ & $\begin{array}{l}\mathrm{Cu} 2 \mathrm{Cl}(\mathrm{OH}) 3 \\
\text { Atacamite }\end{array}$ & $\begin{array}{l}\text { Ian M Bell, } \\
1997, \\
\text { P.2159-2179 \& } \\
\text { M Bouchard, } \\
2003 \text {, } \\
\text { P.2247-2266 \& } \\
\text { Lucia Burigo, } \\
2001, \\
\text { P.1491-1521 }\end{array}$ \\
\hline
\end{tabular}

Table 3. XRF Results of Soil from Ancient Bomb (w \%)

\begin{tabular}{|l|l|l|l|l|l|l|l|l|l|l|l|l|}
\hline Sample & $\mathrm{SiO} 2$ & $\mathrm{~A} 12 \mathrm{O} 3$ & $\mathrm{Fe} 2 \mathrm{O} 3$ & $\mathrm{~K} 2 \mathrm{O}$ & $\mathrm{CaO}$ & $\mathrm{PbO}$ & $\mathrm{TiO} 2$ & $\mathrm{Na} 2 \mathrm{O}$ & $\mathrm{CuO}$ & $\mathrm{SnO} 2$ & $\mathrm{MgO}$ & $\mathrm{Cl}$ \\
\hline Soil & 76.06 & 10.63 & 3.28 & 2.70 & 2.10 & 1.37 & 0.73 & 0.32 & 0.78 & 0.1 & 0.71 & 1.15 \\
\hline
\end{tabular}

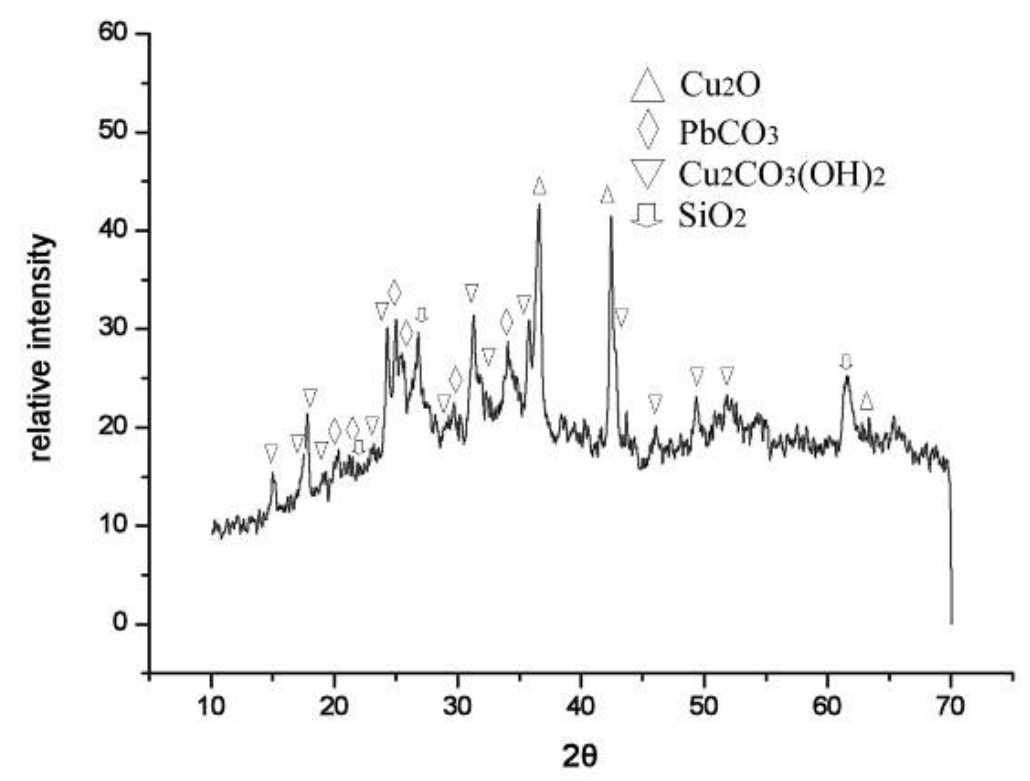

Figure 1. XRD spectra of sample Q6 


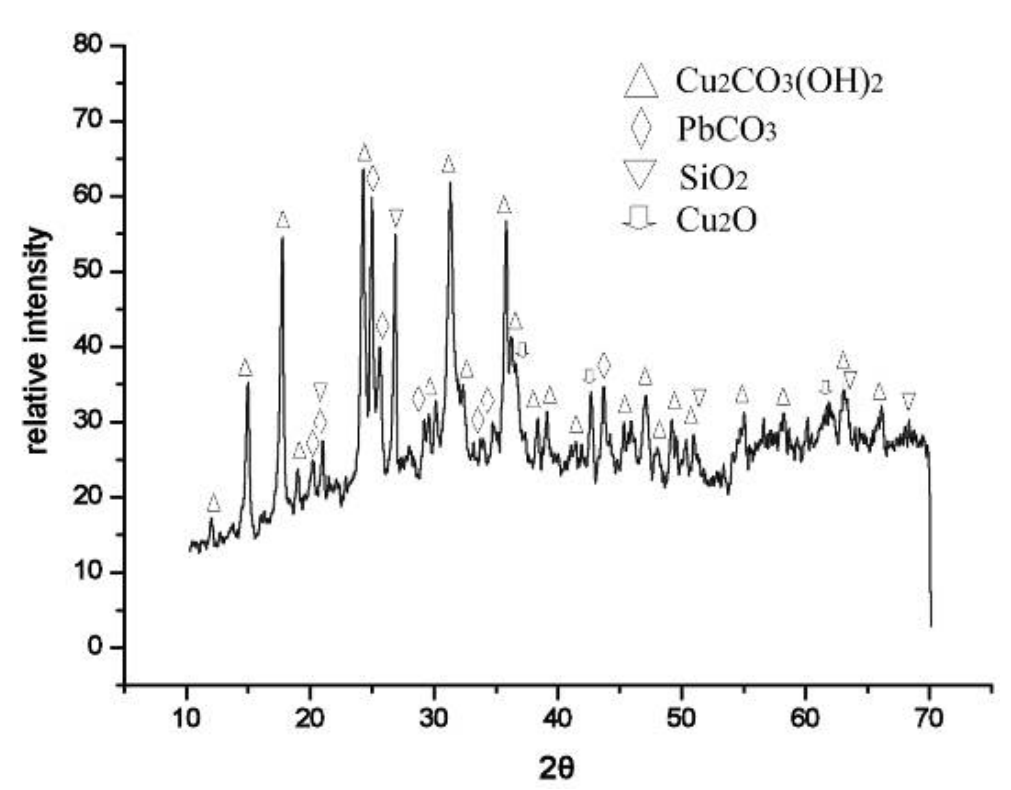

Figure 2. XRD spectra of sample Q38

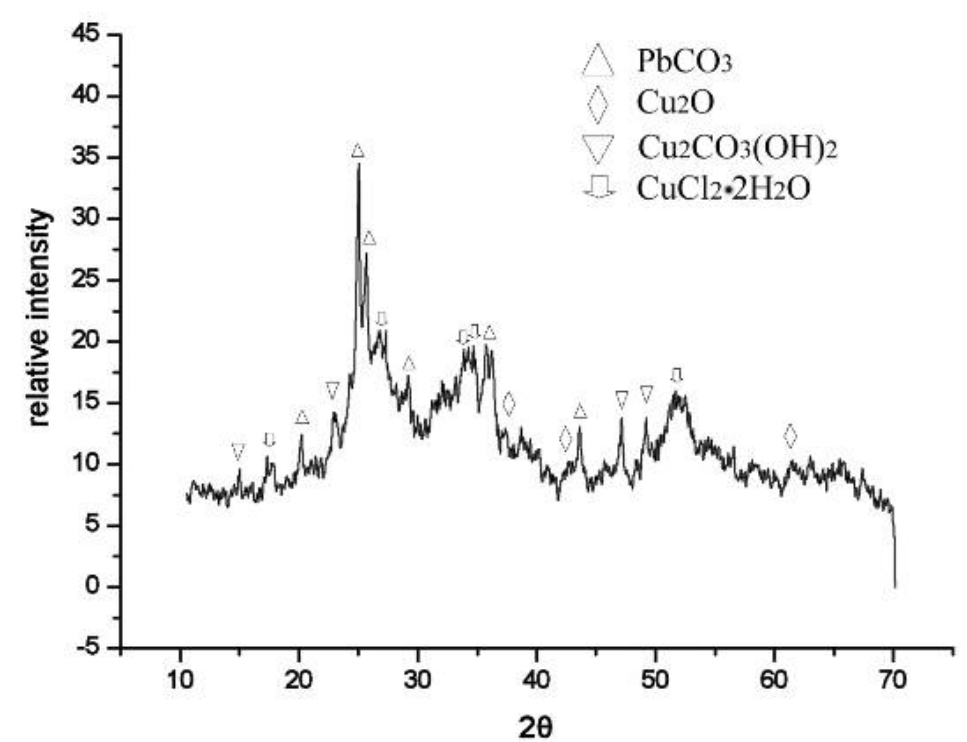

Figure 3. XRD spectra of sample Q41 


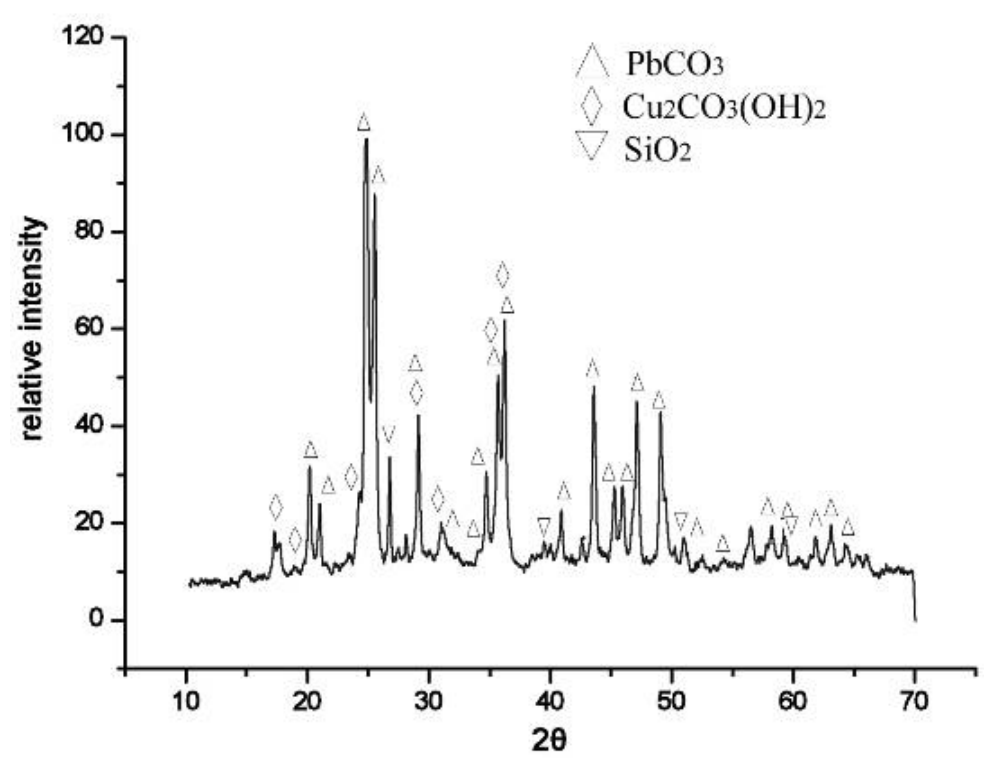

Figure 4. XRD spectra of sample Q42

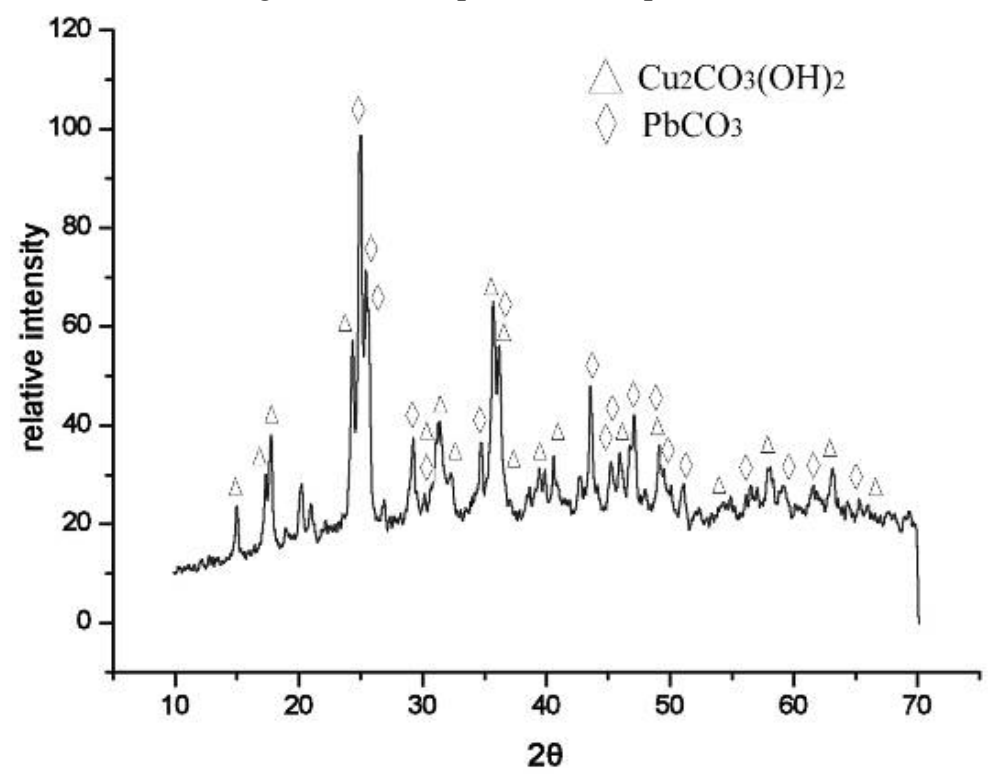

Figure 5. XRD spectra of sample Q43 


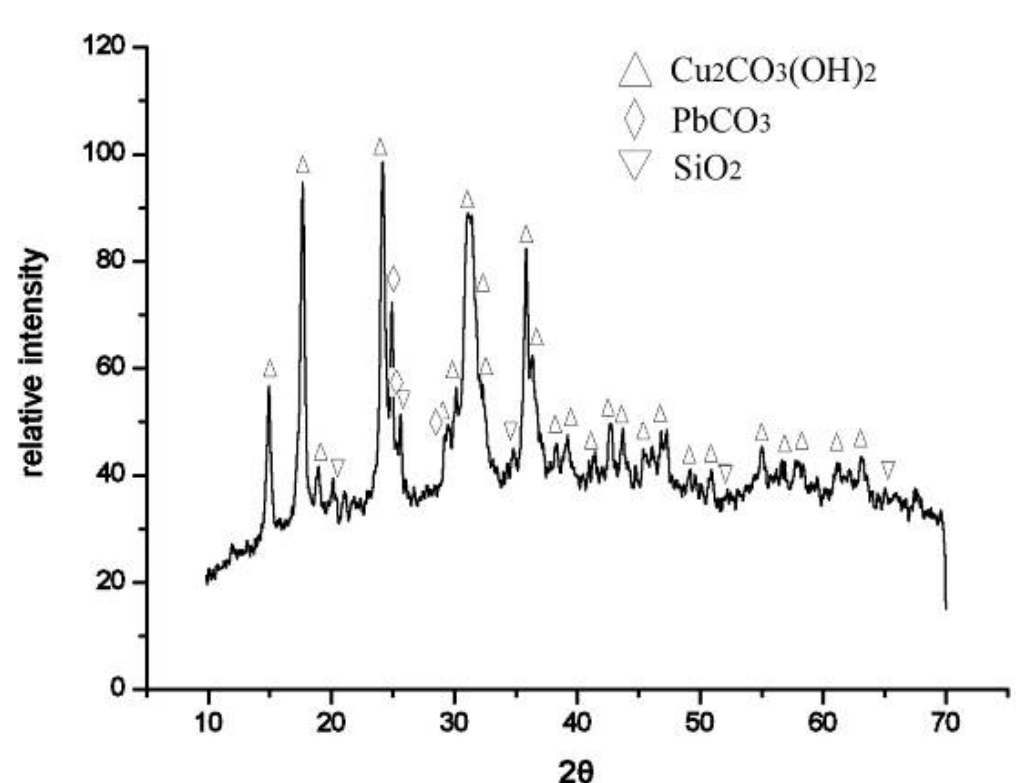

Figure 6. XRD spectra of sample Q46

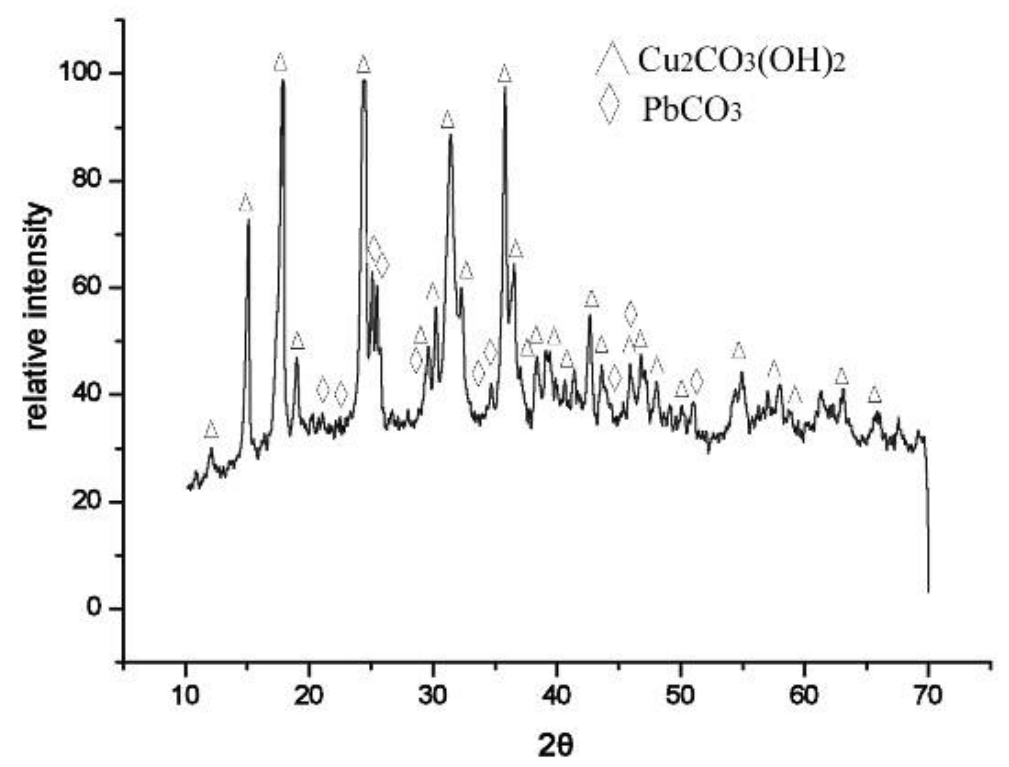

Figure 7. XRD spectra of sample Q48 


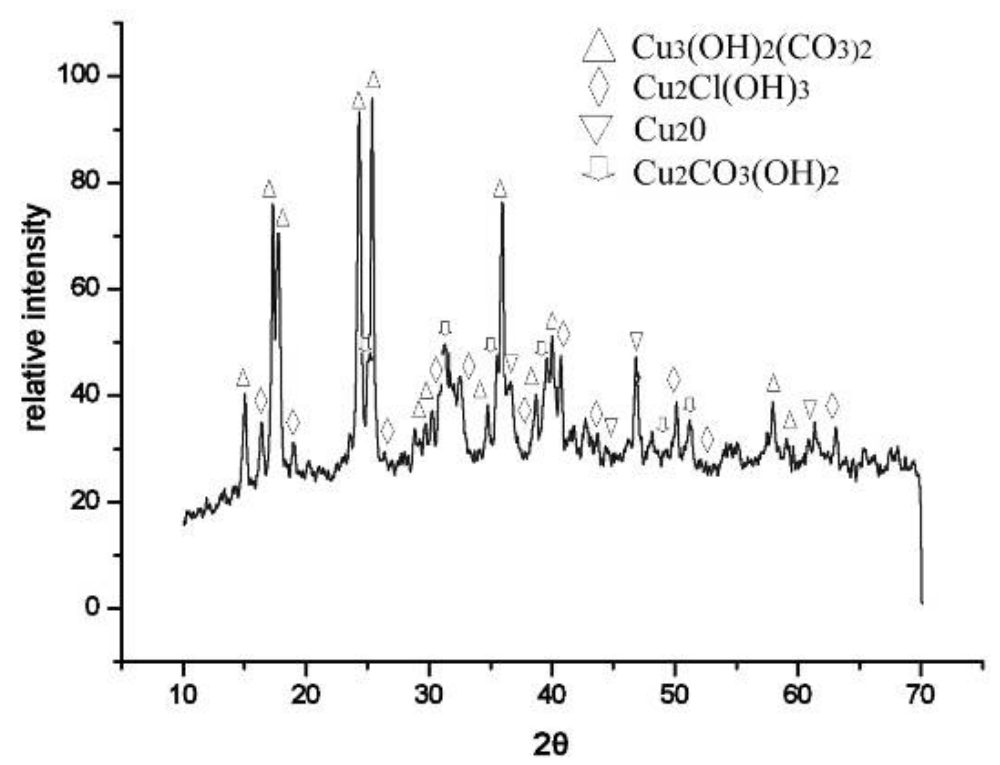

Figure 8. XRD spectra of sample Q50

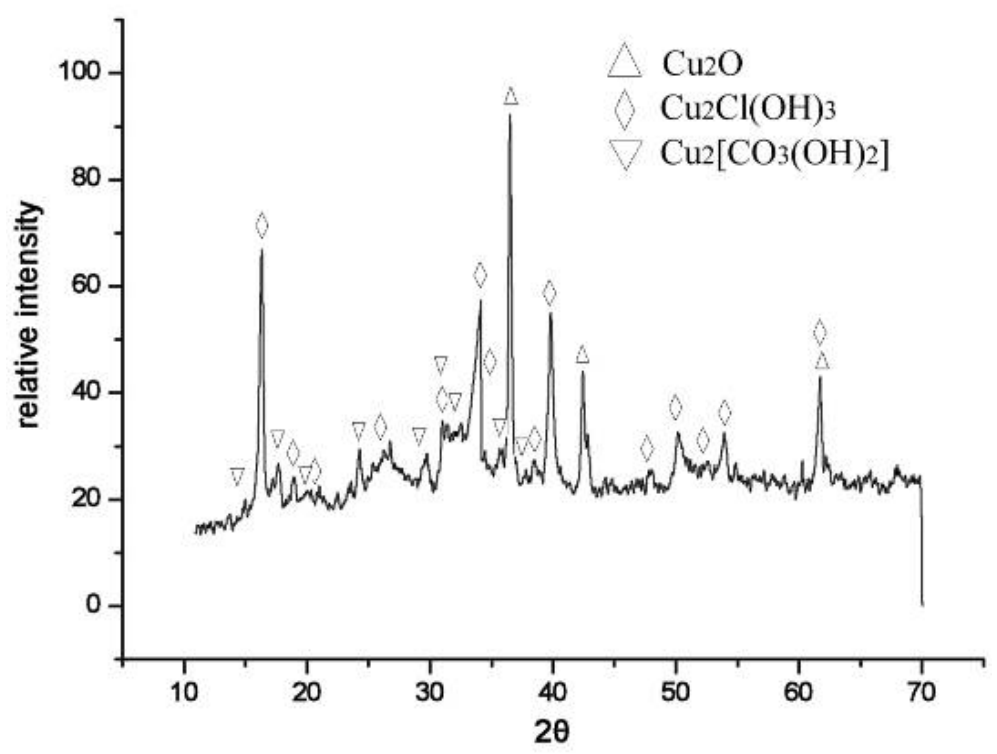

Figure 9. XRD spectra of sample Q52 


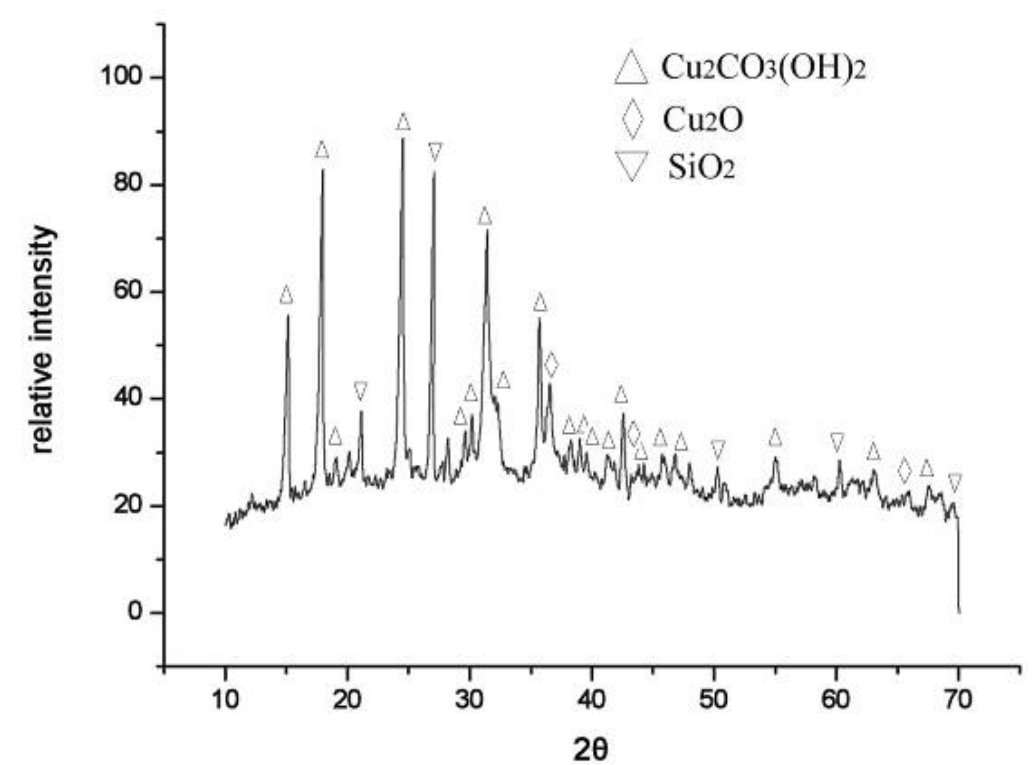

Figure 10. XRD spectra of sample Q54

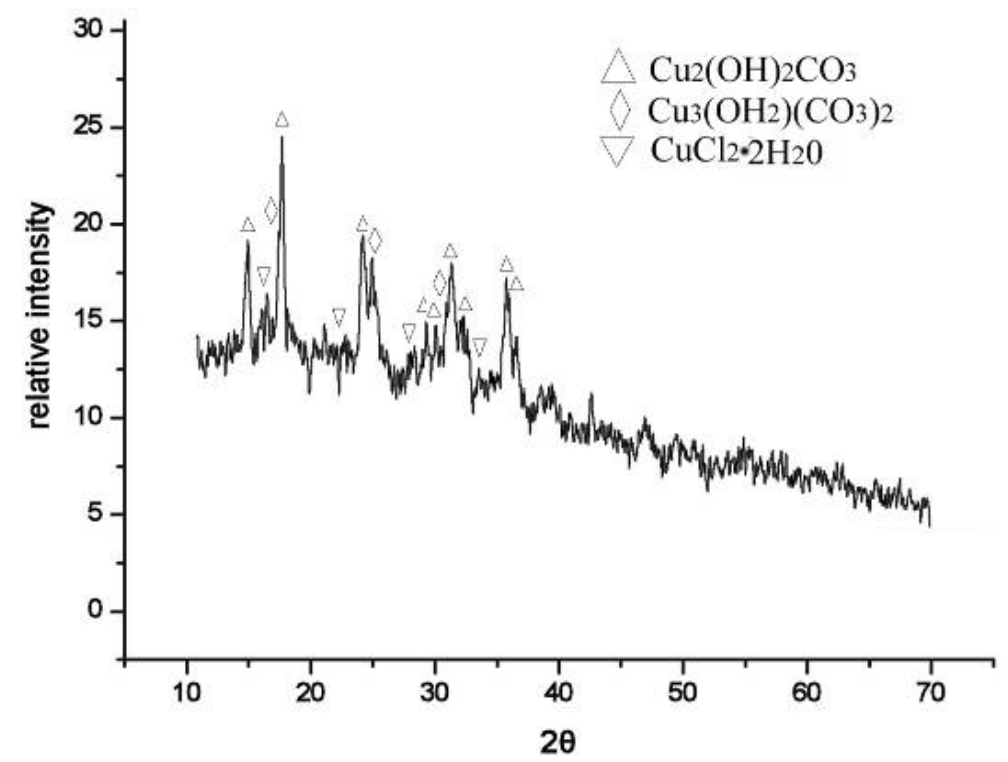

Figure 11. XRD spectra of sample Q57 


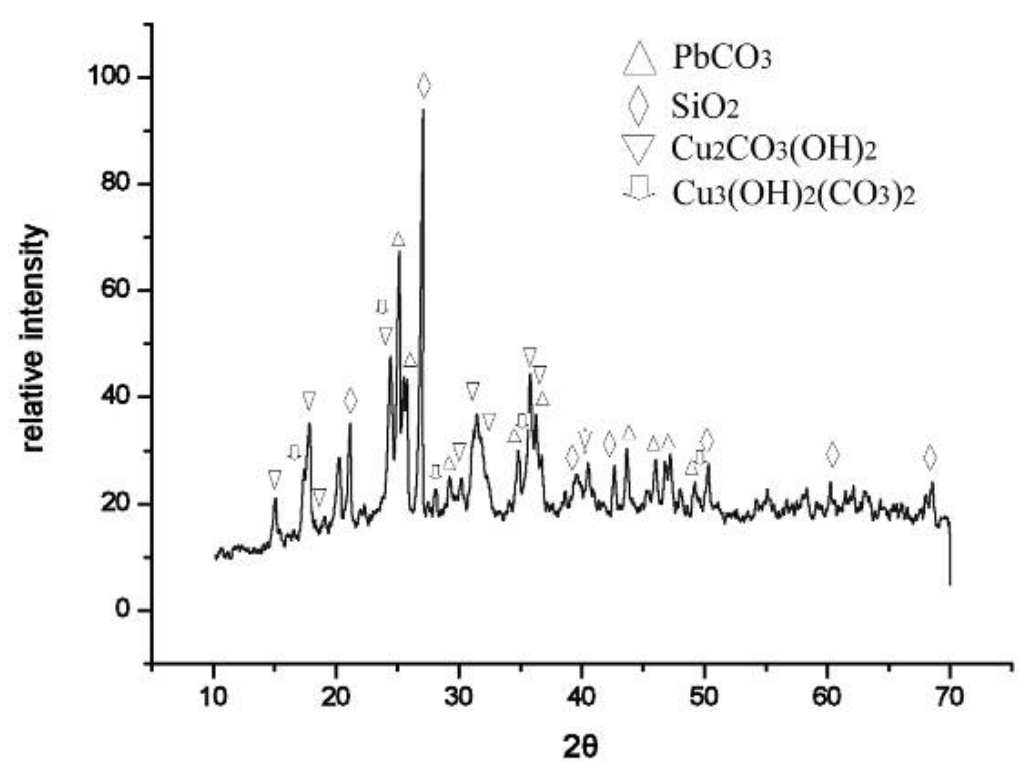

Figure 12. XRD spectra of sample Q74

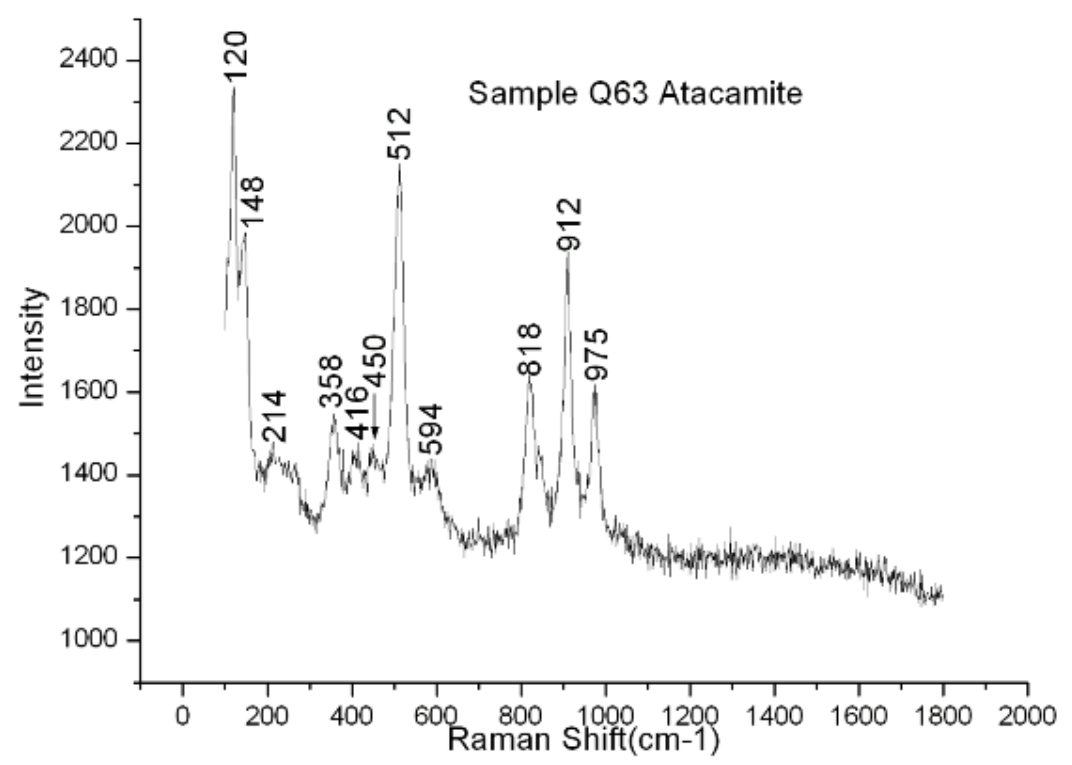

Figure 13. Raman spectra of sample Q63 


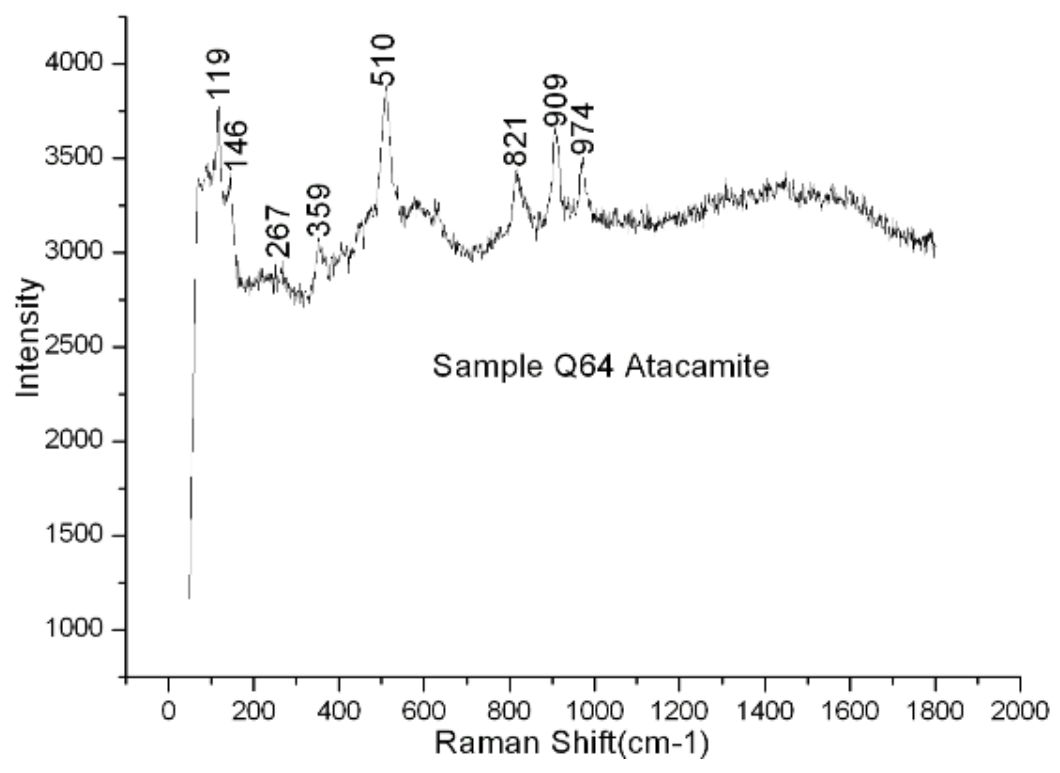

Figure 14. Raman spectra of sample Q64

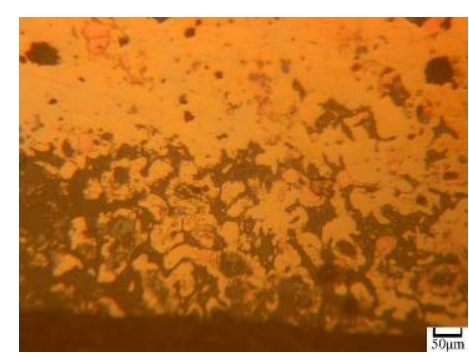

Figure 15. Microstructure of sample Q57

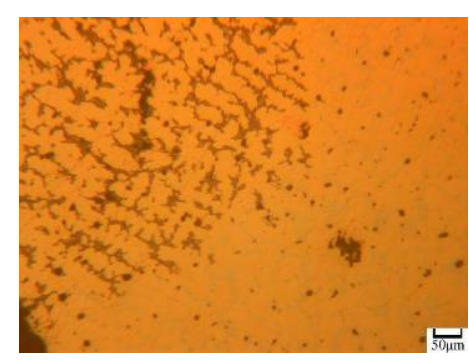

Figure 16. Microstructure of sample Q63

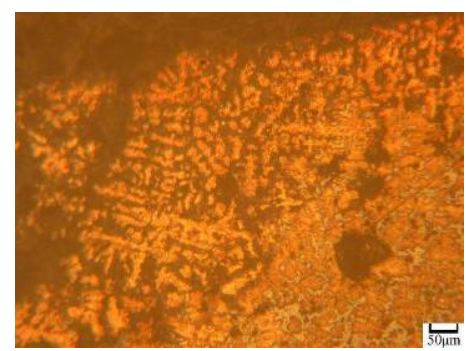

Figure 17. Sample Q64 


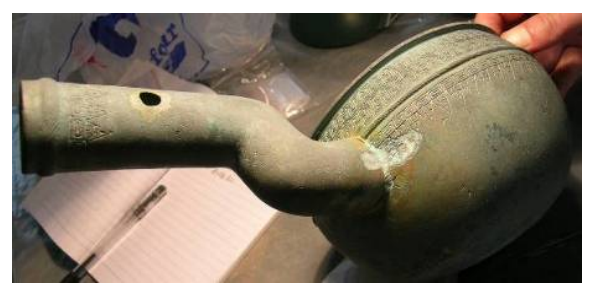

Figure 18. White corrosion of bronze scoop from M4:5

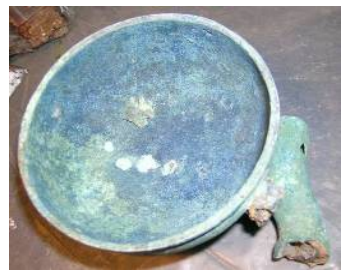

Figure 19. White corrosion of bronze scoop from M5:1

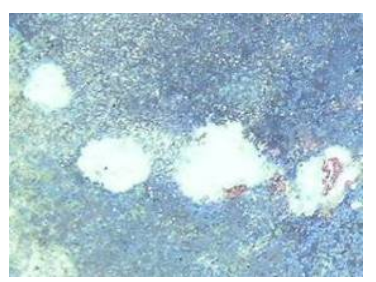

Figure 20. Enlarged drawing of Figure 19

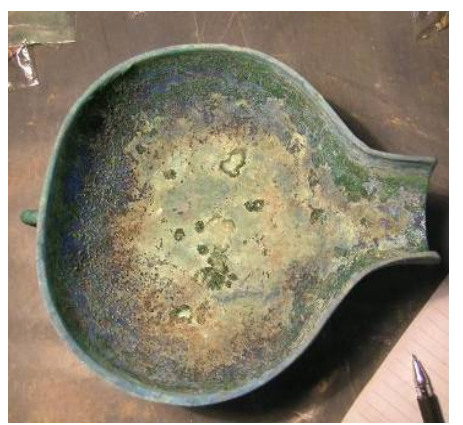

Figure 21. Corrosion of bronze YI from M6:11

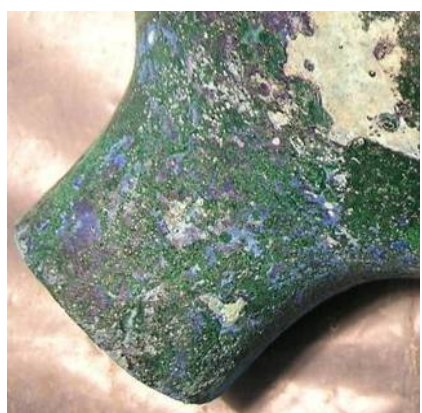

Figure 22. Enlarged drawing of Figure 21 